\title{
Financial Ratios Affecting Disclosure Level in Interim Report of Vietnamese Listed Enterprises
}

\author{
Quoc Thinh TRAN ${ }^{1}$, Ngoc Khanh Dung NGUYEN², Pham Que Anh TO ${ }^{3}$ \\ Received: July 03, 2020 Revised: August 23, 2020 Accepted: September 03, 2020
}

\begin{abstract}
Disclosure level in interim financial reporting is important for information users to make business decisions. This has received much attention from the information users. The article is aimed at determining the factors of financial ratios, which impact on the disclosure level in interim financial reporting. The authors use the ordinary least squares to test. The sample consists of $418 \mathrm{VN} 100$ over a 6-year period from 2014 to 2019 . The results show that there are four factors that positively impact on the disclosure level in interim financial reporting: Enterprise size (SIZE); Liquidity (LIQI); Sales growth (GROW) and Profitability (ROE). The article proposes some policy recommendations to contribute to improving disclosure level in interim financial reporting. Accordingly, State Securities Commission of Vietnam should strengthen the regular inspection of VN100's disclosure level in interim financial reporting and also should enforce strict sanctions or may consider delisting in cases of listed enterprises with incomplete disclosure. The managers of VN100 need to raise the sense of responsibility of information providers to ensure adequate information in interim financial reporting. Investors should also pay attention to the financial ratios of VN100 such as firm size, return-on-equity, liquidity, and sales growth to get useful information and ensure sound business decisions.
\end{abstract}

Keywords: Disclosure Level, Interim Financial Reporting, Financial Ratios, Listed Enterprise, VN100, Vietnam.

JEL Classification Code: O16, M41

\section{Introduction}

Information on financial statements presents economic information for the purpose of assessing the financial position and performance of an enterprise in an accounting period. Meanwhile, the interim financial reporting (IFR) will help users get timely information according to the mid-year accounting period (Schadewitz, 1995). Disclosure level in IFR will help users to understand the situation of the business

${ }^{1}$ First Author and Corresponding Author. Associate Professor, Faculty of Accounting and Auditing, Industrial University of Ho Chi Minh City, Vietnam [Postal address: 86 Nguyen Hong Street, Ward 1, Go Vap District, Ho Chi Minh City, 70000, Vietnam] Tel: (+84) 0903902099, Email: tranthinhktkt@gmail.com

${ }^{2}$ Lecturer, Faculty of Accounting and Auditing, Industrial University of Ho Chi Minh City, Vietnam. Email: tsnguyennogckhanhdung@gmail.com ${ }^{3}$ Expert of BIDV Bank, Vietnam. Email: cntophamqueanh@gmail.com

() Copyright: The Author(s)

This is an Open Access article distributed under the terms of the Creative Commons Attribution Non-Commercial License (https://creativecommons.org/licenses/by-nc/4.0/) which permits unrestricted non-commercial use, distribution, and reproduction in any medium, provided the original work is properly cited. and make decisions timely without having to wait for the annual financial statements (Mathuva, 2012).

Throughout the world, consideration of the influence of factors on disclosure level in IFR has received a lot of attention from researchers. The research focuses on looking at factors of financial ratios or corporate governance or a combination of both and possibly adding some other relevant factors. A typical study focusing on the factors of financial ratios is $\mathrm{Ku}$ and Chandler (2005) or a study focusing on the factors of corporate governance is the one by Albawwat and Basah (2015). While most studies combined factors of financial ratios and corporate governance, and published information is done according to two approaches - mandatory or voluntary. Examples of studies focusing on mandatory disclosure levels in IFR include Schadewitz (1995), Mangena and Tauringana (2007). In addition, some authors focus on researching disclosure issues for both mandatory and voluntary information, such as Schadewitz and Blevins (1998) or even information that is predicted to be published IFR in the future such as Mathuva (2012). In addition, some studies mention the mid-year report, but look at it from the perspective of the Auditor's Efforts (Chu 
\& Ki, 2019); some studies mention independent factors of financial ratios such as the one by Kumar and Paramanik (2020); Nguyen et al. (2020).

In Vietnam, IFR of listed enterprises are prepared and published in compliance with Vietnamese Accounting Standard No. 27 (VAS 27), which presents the interim financial statements (Vietnam Ministry of Finance, 2005). Although this is an issue of concern, in recent years, only a few Vietnamese authors have tackled the disclosure level in IFR. Nguyen and Duong (2018) assess the factors of both financial ratios and corporate governance affecting voluntary information level in IFR, while To (2019) examines factors related to financial ratios. However, the reality of disclosure level in IFR of Vietnamese listed enterprises has not really been properly examined. Currently, most listed enterprises on the Vietnamese stock market have not realized the importance and benefits of disclosure level in IFR (To, 2019). Increasing the usefulness of information in IFR of listed enterprises, in particular, and of the information system on the stock market, in general, will contribute to attracting financial resources, expanding business cooperation and promoting integration and development.

\section{Literature Review}

\subsection{Related Concepts}

\subsubsection{Financial Ratio}

Financial ratio shows the financial structure of an enterprise, which is an important tool to support investors in analyzing financial conditions, health status, financial capacity, as well as development trends of businesses. Schadewitz (1995) argued that financial ratio is made up of short-term loans, and long-term capital sources such as longterm debt, preferred shares, and common shares. Mangena and Tauringana (2007) said that financial capacity is the ability to ensure financial resources for the operations of the business to achieve the business goals. Financial ratio shows, not only the current strength, but also the potential financial strength, prospects and future development trends of enterprises.

\subsubsection{Disclosure Level}

Schadewitz (1995) claimed that disclosure level is a way to provide transparent information of businesses to ensure that shareholders and the public can access information. The information disclosure of listed businesses must ensure completeness, accuracy and timeliness. Disclosure level is a way to make information transparent for businesses to ensure information users can access information fairly and promptly. Disclosure level is information provided to satisfy the needs of users outside the business such as financial analysts, consulting firms, and investors (Mathuva,
2012). The disclosure level is also required by the laws and regulations of a country. These statements must be presented in accordance with the Business Law, the Securities Commission, the accounting authorities and the accounting standards (Vietnam Ministry of Finance, 2005). The disclosure level must be complete, accurate and timely in accordance with the law and ensure that the disclosure level object is responsible for the content of published information. However, disclosure level in the IFR is detailed or shortened depending on many factors (Mangena \& Tauringana, 2007).

\subsubsection{Interim Financial Reporting}

According to Vietnamese Accounting Standard No. 27 (VAS 27), the disclosed information must meet the requirements of updating and interpreting facts. These changes are important to help users understand the fluctuations in financial situation as well as business results of enterprises (Vietnam Ministry of Finance, 2005). International Accounting Standard No. 34 (IAS 34) states that IFR must ensure standards of performance, measurement and disclosure. Information needs to ensure the financial situation, business results and mid-year cash flow (IFRS Foundation, 2020).

\subsection{Theoretical Perspectives}

\subsubsection{Signaling Theory}

Signaling theory posits that disclosure level is considered as signals that businesses convey to investors to make a difference in the quality of their units' operations compared to other entities (Akerlof, 1970). For listed enterprises, managers publish information to the market and send signals to investors. Therefore, disclosure level is one of the tools that enterprises would like covey signals to users. Signaling theory is also described as a party holding information (company) to emit signals about information to the market and one side is information users (investors). This theory is used to verify the influence of factors, namely factors that positively influence financial ratios, such as firm size, profitability, ROE, dividends, sales growth, liquidity, financial leverage, debt structure, etc.

\subsubsection{The Agency Theory}

The agency theory considers a representative relationship as a contract whereby one or more (important) people engage with another person (agent) to perform some services on their behalf (Jensen \& Meckling, 1976). The theory claims that both sides want to maximize their benefits. Therefore, when an agent acts for his own benefit and is detrimental to the owner, the owner will take measures to limit the representative's own interests. The theory used by researchers verifies the influence of specific factors such as firm size, profitability, ROE, dividends, etc. 


\subsection{Previous Studies}

As regards studies that focused on factors of financial ratios only, $\mathrm{Ku}$ and Chandler (2005) investigated the disclosure level in IFR in 117 listed companies in Malaysia in 2001. The results indicate that financial leverage has a positive impact, while two remaining factors have no significant association. Moreover, this research also claims that the firm with the larger size (total assets) will tend to report more quickly than others. A number of studies combining factors of financial ratios and corporate governance have more interest. Schadewitz (1995) studied the factors affecting disclosure levels of 573 listed enterprises on the Helsinki stock exchange (Finland) between 1985 and 1993. The author focused into eight factors, including five factors in two aspects like financial ratios and corporate governance. The research results show that there are two factors in the financial ratios that are affecting the firm size and potential growth, while the capital structure and the level of growth have no influence.

Schadewitz and Blevins (1998) studied 256 non-financial listed companies in Finland between 1985 and 1993 to assess factors affecting disclosure level in IFR in emerging markets. The only variable in the financial ratios mentioned by the authors is the potential growth of the business. However, the research results show that this variable has an opposite impact on disclosure level in IFR. Mangena and Pike (2005) studied factors affecting disclosure level in IFR of 262 listed enterprises in 2001-2002 in United Kingdom, including Scotland, Wales and Northern Ireland. The authors focus on recognizing the factors of financial ratios, corporate governance and a number of other factors such as audit committee. The results show that the variable belonging to financial ratios is the firm size that has a positive impact on the disclosure level in IFR.

Mangena and Tauringana (2007) studied factors affecting disclosure level in IFR of 259 listed companies in the UK. The results show that there are two factors related to financial ratios - firm size and interim dividend - in which both variables mentioned above have a positive impact on disclosure level in IFR. Mathuva (2012) studied the impact of determinants on the information intended to be published in IFR of 91 non-financial enterprises listed on the Nairobi stock exchange, in Kenya from 2009 to 2011. The author mentioned eight factors including four factors of financial ratios and four other factors. The results show that financial leverage, profitability, liquidity, capital costs, and ownership of external institutions are the factors that positively influence disclosure levels in IFR, while firm size and the type of business are said to be unaffected.

Elzahar and Hussainey (2012) measured the level of risk information in IFR narrative sections prepared by 72 UK companies in 2009-2010. The authors use the ordinary least squares regression analysis to examine the impact of firm-specific characteristics and corporate governance mechanisms on narrative risk disclosure levels. The results show that the other firm characteristics (profitability, liquidity, gearing, and cross-listing) are found to have an insignificant relationship with the level of total corporate risk disclosure level in IFR.

Albawwat and Basah (2015) examined the relationship between corporate governance structure and voluntary disclosure of IFR in Jordan, focusing on variables that affect voluntary disclosure of Jordanian listed companies. The dynamic panel system GMM estimation was employed on the data from 72 selected listed companies for the period from 2009 to 2013. The results show that a substantial level of voluntary disclosure is demonstrated in high-level corporate governance awareness and implementation in Jordan. Specifically, the factors of board compensation, number of shareholders, government ownership significantly impact on voluntary disclosure of IFR.

In Vietnam, several studies have looked at the issue. Nguyen and Duong (2018) studied 100 listed enterprises in 2016. The authors studied a combination of factors of financial ratios and corporate governance as well as a number of other factors such as Big4 audit subjects. The results show that only one factor of financial ratios is solvency with the same direction, the other two factors such as firm size and profit have no impact on disclosure level in IFR. To (2019) uses quantitative methods to including 59 best non-financial listed companies in the period from 2016 to 2018. The research model consists of eight factors, the results show that there are only impacting three factors, including firm size, reported interim profit, and interim dividend, and all of them have positive effects.

Based on a review of previous research, the article found that a few domestic and overseas studies had specifically focused on the factors of financial ratios or corporate governance. Foreign studies have not included listed enterprises in Vietnam, while studies on Vietnam have considered only some listed enterprises from Forbes Vietnam or listed enterprises in general. Meanwhile, the top 100 listed companies (VN100) have not been the subjects of previous research. VN100 enterprises make up the largest market capitalization in Vietnam, so the authors choose to study this listing because it will ensure high representativeness and more important information.

\section{Research Design}

\subsection{Research Method}

The authors use quantitative methods through timeseries data panel, as well as the ordinary least square (OLS) method to regress the scale of the research model. The article 
collects IFR information on VN100 from the State Securities Commission of Vietnam website.

\subsection{Research Sample}

The sample includes 418 of 100 listed non-financial enterprises over the past six years. The VN100 was established in Vietnam is 2014 and the most recent information is from 2019. Data is collected in the second quarter of 2020.

\subsection{Description of Research Variables}

The dependent variable is measured by using 19 items published on the IFR under VAS 27 (Appendix). These are the information presented in the notes of IFR. This information does not take into account obvious information published on the financial position, financial performance and cash flows of enterprises.

\subsection{Research Model}

Based on the expert opinion of the State Securities Commission of Vietnam, the authors inherited the model of To (2019) to consider factors of financial ratios to disclosure level in IFR. Therefore, the multivariate regression model is designed as follows:

DISC $=\beta_{0}+\beta_{1} *$ SIZE $+\beta_{2} *$ DEBT $+\beta_{3} *$ PROF $+\beta_{4} *$ LIQI $+\beta_{5}{ }^{*}$ LEVE $+\beta_{6}{ }^{*}$ DIVI $+\beta_{7}{ }^{*}$ GROW $+\beta_{8}{ }^{*}$ ROE $+\varepsilon$

Dependent variable: disclosure level in IFR of VN100 (DISC)
The authors shall use the disclosure level index recorded by weightless measurement method due to its objectivity. This is used to consider disclosure levels in IFR. If the information item is published, it will receive the value of 1 encryption for the data, if unpublished, it will receive the value 0 . Thus, the disclosure level of the business will be calculated as follows:

$$
I_{i j, t}=\frac{\sum_{i=1}^{n j} d_{i j}}{n_{j}}
$$

Where:

$\mathrm{I}_{\mathrm{i}, \mathrm{t}, \mathrm{t}}$ : Information disclosure index of the enterprise, $0 \leq \mathrm{I}_{\mathrm{j}} \leq 1$

$\mathrm{d}_{\mathrm{ij}}: 1$ if information item $\mathrm{i}$ is published; 0 if the information item $i$ is not published.

$n_{j}$ : number of information items on the notes if IFR that the enterprise may publish.

t: figures for 2014-2019

\section{Research Results}

\subsection{Descriptive Statistical Analysis}

According to the statistical results described in Table 2 , the average level of disclosure level in IFR is 0.846, while the standard deviation is negligible. This shows that disclosure level in IFR is quite good. The scale and profitability of VN100 are relatively high, with an average of 12.182 and 11.126 , respectively, as this is the top 100 leading enterprises in Vietnam. Meanwhile, sales

Table 1: Description of independent variables used in the regression model

\begin{tabular}{|l|l|l|l|}
\hline $\begin{array}{l}\text { Variable } \\
\text { name }\end{array}$ & \multicolumn{1}{|c|}{ Description } & \multicolumn{1}{|c|}{ Measurement } & \multicolumn{1}{c|}{ Examples for prior studies } \\
\hline SIZE & Firm size & Logarit of total assets & $\begin{array}{l}\text { Schadewitz (1995); Mangena \& Pike (2005); Ku \& } \\
\text { Chandler (2005); Mangena \& Tauringana (2007); } \\
\text { Mathuva (2012); Nguyen \& Duong (2018); To (2019) }\end{array}$ \\
\hline DEBT & Debt structure & Ratio of debt to equity & Schadewitz (1995); To (2019) \\
\hline PROF & $\begin{array}{l}\text { Profit after tax of } \\
\text { interim }\end{array}$ & Logarithm of interim profit after tax & $\begin{array}{l}\text { Ku \& Chandler (2005); Mathuva (2012); Nguyen \& } \\
\text { Duong (2018); To (2019) }\end{array}$ \\
\hline LIQI & Liquidity & $\begin{array}{l}\text { The ratio of short-term assets to } \\
\text { short-term debt }\end{array}$ & $\begin{array}{l}\text { Mathuva (2012); Elzahar \& Hussainey (2012); } \\
\text { Nguyen \& Duong (2018); To (2019) }\end{array}$ \\
\hline LEVE & Financial leverage & Ratio of total liabilities to total assets & $\begin{array}{l}\text { Ku và Chandler (2005); Mathuva (2012); } \\
\text { To (2019) }\end{array}$ \\
\hline DIVI & Interim dividends & Logarit of interim dividend payable & Mangena \& Tauringana (2007); To (2019) \\
\hline GROW & Sales growth rate & $\begin{array}{l}\text { (Sales Y1 - Sales Yo) x 100) / Sales } \\
\text { Yo }\end{array}$ & $\begin{array}{l}\text { Schadewitz (1995); Schadewitz \& Blevins (1998); Ku } \\
\text { \& Chandler (2005); To (2019) }\end{array}$ \\
\hline ROE & Profitability ratio & The ratio of profit after tax to equity & Elzahar \& Hussainey (2012); To (2019) \\
\hline
\end{tabular}


growth and ROE are also quite high, $31.4 \%$ and $20.8 \%$, respectively. Due to the effectiveness of VN100's top, the dividend payment is also quite good, with an average of 6.415. Besides, the liquidity is generally quite good, an average of 1.271. For financial leverage and debt structure at safe level, the average is $31.6 \%$ and $25.8 \%$, respectively. In general, the independent variables have negligible standard deviations.

\subsection{Testing the Correlation Coefficient Matrix}

The results of correlation testing showed that these variables are all correlated with the dependent variables with significance level of less than $5 \%$ Sig. The correlation coefficients of the variables are at a relative level (Table 3 ).

\subsection{Evaluation of the Suitability of the Model}

The result shows that Adjusted R Square is 0.412 and this means that the variation of the disclosure level variable is explained by the independent variables corresponding to $41.2 \%$ (Table 4).

\subsection{Verification of Conformity of the Model}

The F test in ANOVA is an assumption about the suitability of the overall linear regression model. Experiments are used to assess the linear relationship between dependent and independent variables.

Ho: $\beta i=0$ : The variables included in the model do not impact on the disclosure level.

H1: \#i \# 0: The variables included in the model impact on the disclosure level.

The result shows the Sig value is 0.000 , less than $5 \%$ significant (Table 5). This suggests that the Ho hypothesis was rejected. So, the regression model with the above independent variables has an influence on the disclosure level and the model data is considered appropriate.

\subsection{Regression Results}

Based on the testing results above, the authors conducted regression for the disclosure level model based on independent variables. The results are as follows:

The regression analysis results of the model in Table 6 will be based on the standardized regression coefficients because they are more economical. VIF data show that the model has no multicollinearity phenomenon. The results show that there are 4 variables impact on the disclosure level in IFR. This research result is quite similar to To (2019). Regression model is presented as follows:

$$
\begin{aligned}
\mathrm{DISC}= & 0.216 * \mathrm{SIZE}+0.1115 * \mathrm{LIQI}+0.174 * \mathrm{GROW} \\
& +0.197 * \mathrm{ROE}
\end{aligned}
$$

Table 2: Descriptive Statistics

\begin{tabular}{|l|c|c|c|c|c|}
\hline Variables & $\mathbf{N}$ & Minimum & Maximum & Mean & Std. Deviation \\
\hline DISC & 418 & .562 & .902 & .846 & .564 \\
\hline SIZE & 418 & 11.141 & 16.902 & 12.182 & .258 \\
\hline DEBT & 418 & .001 & 3.114 & 11.126 & .588 \\
\hline PROF & 418 & 9.642 & 12.904 & 1.271 & .606 \\
\hline LIQI & 418 & .501 & 4.517 & .316 & .145 \\
\hline LEVE & 418 & .004 & 11.471 & 6.415 & .314 \\
\hline DIVI & 418 & .002 & 1.148 & .08 & .461 \\
\hline GROW & 418 & .642 & .802 & .045 \\
\hline ROE & 418 & .015 & & .208 \\
\hline
\end{tabular}

Table 3: Correlations

\begin{tabular}{|c|l|c|c|c|c|c|c|c|c|c|}
\hline & \multicolumn{1}{|c|}{ Variables } & DISC & SIZE & DEBT & PROF & LIQI & LEVE & DIVI & GROW & ROE \\
\hline \multirow{3}{*}{ DISC } & Pearson Correlation & 1 & $.381^{* *}$ & -.142 & .442 & $.196^{* *}$ & -.164 & .305 & $.154^{* *}$ & $.133^{* *}$ \\
\cline { 2 - 32 } & Sig. (2-tailed) & & .000 & .001 & .000 & .005 & .001 & .000 & .000 & 413 \\
\cline { 2 - 12 } & $\mathrm{N}$ & 418 & 418 & 418 & 418 & 418 & 418 & 418 & 418 \\
\hline
\end{tabular}


Table 4: Model Summary

\begin{tabular}{|l|c|c|c|c|}
\hline Model & $\mathbf{R}$ & R Square & Adjusted R Square & Std. Error of the Estimate \\
\hline DISC & .612 & .498 & .412 & 1.417 \\
\hline
\end{tabular}

Table 5: ANOVA

\begin{tabular}{|c|l|c|c|c|c|c|}
\hline \multicolumn{2}{|c|}{ Model } & Sum of Squares & df & Mean Square & F & Sig. \\
\hline \multirow{3}{*}{ DISC } & Regression & .087 & 8 & .012 & 12.418 & .000 \\
\cline { 2 - 7 } & Residual & .261 & 410 & .001 & & \\
\cline { 2 - 7 } & Total & .348 & 418 & & & \\
\hline
\end{tabular}

Table 6: Coefficients

\begin{tabular}{|c|c|c|c|c|c|c|c|c|}
\hline & \multirow{2}{*}{ Model } & \multicolumn{2}{|c|}{$\begin{array}{l}\text { Unstandardized } \\
\text { Coefficients }\end{array}$} & \multirow{2}{*}{$\begin{array}{c}\begin{array}{c}\text { Standardized } \\
\text { Coefficients }\end{array} \\
\text { Beta }\end{array}$} & \multirow{2}{*}{$t$} & \multirow{2}{*}{ Sig. } & \multicolumn{2}{|c|}{ Collinearity Statistics } \\
\hline & & B & Std. Error & & & & Tolerance & VIF \\
\hline \multirow[t]{9}{*}{1} & (Constant) & .239 & .109 & & 2.198 & .030 & & \\
\hline & SIZE & .148 & .009 & .216 & 2.187 & .000 & .641 & 1.412 \\
\hline & DEBT & -.028 & .010 & -.073 & 1.154 & .114 & .654 & 1.621 \\
\hline & PROF & .013 & .001 & .065 & 1.043 & .328 & .712 & 1.038 \\
\hline & LIQI & .053 & .002 & .115 & 2.461 & .000 & .621 & 1.149 \\
\hline & LEVE & -.018 & .001 & -.067 & 1.244 & .514 & .634 & 1.472 \\
\hline & DIVI & .036 & .010 & .092 & 1.028 & .217 & .618 & 1.521 \\
\hline & GROW & .083 & .005 & .174 & 2.448 & .000 & .701 & 1.234 \\
\hline & ROE & .103 & .004 & .197 & 2.612 & .000 & .783 & 1.102 \\
\hline
\end{tabular}

\section{Conclusion and Policy Recommendations}

\subsection{Conclusion}

Based on the model by To (2019), the authors have studied 418 samples of VN100 over a period of six years from 2014 to 2019. The results have shown that out of eight independent variables used in the model, four variables positively impact on the disclosure level in IFR including SIZE, ROE, GROW, LIQI. In particular, SIZE variable has the largest impact on disclosure level in IFR. Based on these results, in order to contribute to raising the disclosure level in IFR of VN100, the State Securities Commission of Vietnam should strengthen the regular inspection of VN100's disclosure level in IFR; it should pay special attention to VN100 with smaller size, where ROE is not high, the liquidity not good, and sales growth is not large. In addition, State agencies of Vietnam also need to have strict sanctions or may consider delisting in cases of listed enterprises with incomplete disclosure. The managers of VN100 need to raise the sense of responsibility of information providers to ensure adequate information in IFR. Investors should also pay attention to VN100 with large size, high ROE, good liquidity, and high sales growth to get useful information and ensure making sound business decisions.

\subsection{Policy Recommendations}

From the above research results, the authors propose a number of policy recommendations to the State Securities Commission of Vietnam, managers of VN100 as well as investors to contribute to improving the disclosure level in IFR.

The State Securities Commission of Vietnam should strengthen the regular check-up of disclosure level in IFR of VN100 to contribute to improving information quality. Moreover, the State Securities Commission of Vietnam should pay special attention to VN100 with smaller size, where ROE is not high, the liquidity not good, and sales growth is not large. These signs of VN100 often tend not to guarantee the adequacy of information provided on the IFR. In addition, the State agency of Vietnam also needs to have strict sanctions and penalties for cases where VN100 publishes insufficient information. If VN100 rules are 
violated a few times, the State agency may consider delisting, and this guarantees user information rights.

The managers of VN100 need to raise the sense of responsibility of the information providers. The information on the IFR should ensure completeness and transparency. This is a long-term benefit of the business because investors will have confidence in VN100 to provide sufficient information. Managers should not hide or provide information because otherwise investors will lose confidence. This will seriously influence on the attraction of investment capital and it will also affect the business performance of VN100.

Investors should also pay attention to VN100 with large size, high ROE, good liquidity, high sales growth. These are characteristics that ensure VN100 has sufficient level of information disclosure on the IFR. This helps investors get assured information to make business decisions.

\section{References}

Akerlof, G. A. (1970). The market for lemons: Quality uncertainty and the market mechanism. The Quarterly Journal of Economics, 84(3), 488-500.

Albawwat, A. H., \& Basah, M. Y. A. (2015). The Impact of Shariah Approved Companies on the Relationship between Corporate Governance Structure and Voluntary Disclosure of Interim Financial Reporting in Jordan. International Journal of Academic Research in Accounting, Finance and Management Sciences, 5(2), 66-85.

Chu, J., \& Ki, E. S. (2019). Do Auditor's Efforts of Interim Review Curb the Analyst Forecast's Walkdown? Journal of Asian Finance, Economics and Business, 6(2), 45-54. http:/ doi:10.13106/jafeb.2019.vol6.no2.45.

Elzahar, H., \& Hussainey, K. (2012). Determinants of narrative risk disclosure levels in UK Interim reports. The Journal of Risk Finance, 13(2), 133-147. https:/DOI 10.1108/15265941211203189.

IFRS Foundation. (2020). Interim Financial Reporting. London, UK: IFRS Foundation. Retrieved March 30, 2020, from: https://www.ifrs.org/issued-standards/list-of-standards/ias-34interim-financial-reporting/

Jensen, M. C., \& Meckling, W. H. (1976). The theory of the firm: Managerial behavior, agency costs and ownership structure, Journal of Financial Economics, 3(4), 305-360.
Ku, I. K. N. I., \& Chandler, R. (2005). DISCs in the quarterly reports of Malaysian companies. Financial Reporting, Regulation \& Governance, 4(1), 1-25.

Kumar, K., \& Paramanik, P. N. (2020). Nexus between Indian Economic Growth and Financial Development: A Non-Linear ARDL Approach. Journal of Asian Finance, Economics and Business, 7(6), 109-116. http:/ doi:10.13106/jafeb.2020.vol7. no6.109.

Mathuva, D. (2012). The determinants of forward-looking DISCs in Interim reports for non-financial firms: Evidence from a developing country. International Journal of Accounting and Financial Reporting, 2(2). https://doi.org/10.5296/ijafr. v2i2.2257

Mangena, M., \& Pike, R. (2005). The effect of audit committee shareholding, financial expertise and size on interim financial DISCs. Accounting and Business Research, 35(4), 327-349.

Mangena, M., \& Tauringana, V. (2007). Corporate compliance with non-mandatory statements of best practice: The case of the ASB statement on Interim reports. European Accounting Review, 16(2), 399-427.

Nguyen, H. C., \& Duong, N. N. Q. (2018). Disclose arbitrary information in interim financial statements of companies listed on Vietnam's stock market. Journal of Economic Research, 8, 32-37.

Nguyen, P. H., Tsai, J. F., Kumar, V. A., \& Hu, Y. C. (2020). Stock Investment of Agriculture Companies in the Vietnam Stock Exchange Market: An AHP Integrated with GRA-TOPSISMOORA Approaches. Journal of Asian Finance, Economics and Business, 7(7), 113-121. https://doi.org/10.13106/ jafeb.2020.vol7.no7.113

Schadewitz, H. (1995). Financial and Nonfinancial Information in Interim reports: Determinants and Implications. Acta University Economicae Helsingiensis A, 124, Retrieved March 30, 2020, from: https://aaltodoc. aalto.fi/bitstream/handle/123456789/11181/a 124 . pdf? sequence $=4 \&$ is Allowed $=y$

Schadewitz, H. J., \& Blevins, D. R. (1998). Major determinants of interim DISCs in an emerging market. American Business Review, 20(2), 33-46.

To, P. Q. A. (2019). Factors affecting the level of information disclosure level on interim financial statements of listed companies according to Forbes Vietnam. Journal of Finance, 7(192), 27-30. [Vietnamese]

Vietnam Ministry of Finance. (2005). Vietnam Accounting Standard System. Hanoi, Vietnam: Hanoi Publishing House. 
Appendix: List of information disclosed in IFR

\begin{tabular}{|c|c|}
\hline No. & List of item \\
\hline 1 & Form of capital ownership. \\
\hline 2 & Business area. \\
\hline 3 & Business lines. \\
\hline 4 & Characteristics of the business operations of the enterprise in the accounting period affect the financial statements. \\
\hline 5 & Annual accounting period (beginning and ending dates). \\
\hline 6 & Currency unit used in accounting. \\
\hline 7 & Accounting regime applied. \\
\hline 8 & Statement of compliance with accounting standards and regulations. \\
\hline 9 & Applicable accounting policies. \\
\hline 10 & Explain the seasonality or cyclicality of business activities in the interim period. \\
\hline 11 & $\begin{array}{l}\text { The nature and value of items affecting assets, liabilities, equity loss, net income, or cash flows are considered to be } \\
\text { abnormal factors due to their nature, size or impact their action. }\end{array}$ \\
\hline 12 & $\begin{array}{l}\text { Movements in accumulated equity as of the date of IFR as well as corresponding notes are comparable in the same } \\
\text { accounting period in the most recent fiscal year. }\end{array}$ \\
\hline 13 & $\begin{array}{l}\text { The nature and value of changes in accounting estimates that have been reported in previous IFR of the current year } \\
\text { or changes in accounting estimates have been reported in previous years, if changes are made. This change has } \\
\text { materially affected the current interim period. }\end{array}$ \\
\hline 14 & Issue, repurchase and return of debt and equity securities. \\
\hline 15 & Dividends paid (total or per share) of ordinary shares and other stocks. \\
\hline 16 & Sales and departmental results by business sector or geographic area, based on the division of the division report. \\
\hline 17 & Material events arising after the balance sheet date have not been reflected in IFR. \\
\hline 18 & $\begin{array}{l}\text { Impact of changes in the operating structure of an enterprise in the interim period (consolidation, acquisition or } \\
\text { liquidation of subsidiaries, long-term investments, restructuring and ceasing operations). }\end{array}$ \\
\hline 19 & Changes in contingent (contingent) liabilities or accidental assets since the end of the most recent accounting period. \\
\hline
\end{tabular}

Source: Vietnam Ministry of Finance (2005) 